


\title{
Current Trends in the Development of International Terrorism: A Current Understanding of the Problem
}

\author{
DOI: https://doi.org/10.46398/cuestpol.3969.36
}

\author{
Ivo Svoboda * \\ Tymur O. Loskutov ** \\ Oleksandra B. Severinova ${ }^{* * *}$ \\ Olha M. Peresada **** \\ Andriy O. Shulha *****
}

\section{Abstract}

The study examines the development of international terrorism and the problem of its definition. Consequently, the objective of the study was to generate a systemic view of international terrorism and to identify current trends in its development. A structural and functional analysis of international terrorism as a political phenomenon was used. Based on the analytical model provided, the development of international terrorism was divided into periods based on political and geographical zoning. Three consistent principles determine the key characteristics of international terrorism as a rational strategy of unconventional political struggle: the transition to asymmetrical actions, attacks on symbolic objects, and influencing public opinion as the main objective. This triality of characteristics linked to a model of the political process defines the existence of international terrorism as a phenomenon and provides a key to understanding its dynamics. It is concluded that there are four periods in the development of international terrorism, divided into two cycles with breaking points, ascending, and descending phases. The proposed periodization of the development of international terrorism is

\footnotetext{
Associate Professor, Guarantor of Security Management Studies, Ambis - Vysoká škola, Praha, Czech Republic. ORCID ID: https://orcid.org/oooo-0002-0941-4686. Email: svobodaivo985@gmail.com

** Doctor of Law, Professor, Department of Organization of Pre-trial Investigation of Kryvyi Rih Educational and Scientific Institute, Donetsk Law Institute of the Ministry of Internal Affairs of Ukraine, Kryvyi Rih, Ukraine. ORCID ID: https://orcid.org/oooo-0002-2686-9201. Email: Tymloskutov@ukr.net

*** PhD in Law, Associate Professor, Department of State and Legal Disciplines and Public Administration, Faculty \#3, Donetsk Law Institute of the Ministry of Internal Affairs of Ukraine, Mariupol, Ukraine. ORCID ID: https://orcid.org/oooo-ooo3-3013-9815. Email: alex4sev@gmail.com

**** PhD in Law, Associate Professor, Head of Department of State and Legal Disciplines and Public Administration, Faculty \#3, Donetsk Law Institute of the Ministry of Internal Affairs of Ukraine, Mariupol, Ukraine. ORCID ID: https://orcid.org/oooo-ooo1-7199-1938. Email: peresada.olha@ gmail.com

***** PhD in Law, Associate Professor, Department of State and Legal Disciplines and Public Administration, Faculty \#3, Donetsk Law Institute of the Ministry of Internal Affairs of Ukraine, Mariupol, Ukraine. ORCID ID: https://orcid.org/oooo-ooo1-5524-5433. Email: shulhadon1@ukr.net
} 
Ivo Svoboda, Tymur O. Loskutov, Oleksandra B. Severinova, Olha M. Peresada y Andriy O. Shulha

582 Current Trends in the Development of International Terrorism: A Current Understanding of the
Problem

based on the identification of the centers as political-geographical areas, where contradictions are configured and the political struggle that is part of the logic of the terrorist strategy.

Keywords: international terrorism; political extremism; periodisation; civil conflicts; asymmetric actions

\section{Tendencias actuales en el desarrollo del terrorismo internacional: una comprensión actual del problema}

\section{Resumen}

El estudio examina el desarrollo del terrorismo internacional y el problema de su definición. En consecuencia, el objetivo del estudio fue generar una visión sistémica del terrorismo internacional e identificar las tendencias actuales en su desarrollo. Se utilizó un análisis estructural y funcional del terrorismo internacional como fenómeno político. Sobre la base del modelo analítico proporcionado, el desarrollo del terrorismo internacional se dividió en períodos sobre la base de la zonificación política y geográfica. Tres principios consistentes determinan las características clave del terrorismo internacional como estrategia racional de lucha política no convencional: la transición a acciones asimétricas, ataques a objetos simbólicos, e influir en la opinión pública como objetivo principal. Esta tríada de características vinculadas a un modelo del proceso político define la existencia del terrorismo internacional como un fenómeno y proporciona una clave para comprender su dinámica. Se concluye que hay cuatro períodos en el desarrollo del terrorismo internacional, divididos en dos ciclos con puntos de ruptura, fases ascendentes y descendentes. La periodización propuesta del desarrollo del terrorismo internacional se basa en la identificación de los centros como zonas político-geográficas, donde se configuran las contradicciones y la lucha política que es parte de la lógica de la estrategia terrorista.

Palabras clave: terrorismo internacional; extremismo político; periodización; conflictos civiles; acciones asimétricas. 


\section{Introduction}

\section{Topicality}

It was believed that a number of reasons contributed to the spread of international terrorism: the defeat of the Arab countries in the Six-Day War of 1967, which revealed their military inability to resist Israeli claims to the Palestinian territory, which encouraged Arab militants to seek asymmetrical responses to military superiority; the spread of guerrilla movements that chose the terror tactics in Latin America; spread of anti-government and radical movements in the United States and Western Europe against the background of anti-war sentiments (Jenkins, 1978). During the decades of the 1970's and 2020's, international terrorism, as a phenomenon of world politics, underwent changes and transformations associated with changes in the international situation and world society as a whole.

These changes took place in several directions. The driving forces of international terrorism have changed; new conflict zones emerged, where conditions arose for the transition to asymmetric actions characteristic of terrorism; as world politics changed, so did the policies of countries in support of international terrorism; there were changes in the organization, forms and methods of conducting terrorist activity by its actors. International terrorism is a rapidly changing dynamic phenomenon, remaining one of the leading factors and threats to world politics.

\section{Literature review}

In modern academic research on the problem of international terrorism, one can identify both the waves caused by the growth and decline of interest in this phenomenon, and the conceptual division into the socalled traditional and critical studies of terrorism. The root of academic controversy is in the very definition of terrorism in general, and international terrorism in particular, which constitutes a "definition dilemma" (Scremin, 2020). According to. Scremin's apt definition, this dilemma manifests itself at the academic, political and operational levels, which, accordingly, hinders the creation of a single conceptual framework for the study of terrorism; distorts the political discourse on terrorism and delegitimises the means of combating it; and, ultimately, negatively affects international cooperation efforts in the fight against terrorism. The inconsistency of the basic understanding of the definition, which is a reflection of the lack of a stable consensus on the essence of the phenomenon, affects the whole understanding of the problems of its structure and dynamics. 
Ivo Svoboda, Tymur O. Loskutov, Oleksandra B. Severinova, Olha M. Peresada y Andriy O. Shulha

The modern academic paradigm regarding the phenomenon of international terrorism began to take shape after the terrorist attack of September 11, 2001, and the ensuing War on Terror. Despite the extensive experience of understanding international terrorism in previous decades, it is characterised by three theoretical forces, which, in fact, create a definition dilemma. Impressive analysis of current legal framework for the definition of terrorism in (Margariti, 2017). First, terrorist activity can be equated with the phenomena of mass political violence with a wide range of historical and contemporary examples (Monaghan et al., 2011; Sysoev, 2017; Tilly, 2004).

Second, there may be confusion in the phenomena of "insurgency - guerrilla warfare - (international) terrorism" (Garrison, 2004), or "revolution - terrorism" (Anderson, 2015). This version of a broad approach allows discussing the role of even the ISIS movement as an international terrorist group (Kane, 2018). Third, in the context of socalled critical research on terrorism, this concept can be "deconstructed" as a discursive phantom created by states to legitimise their own repressive policies against certain discriminated sections of the population. This trend is rightly associated with the approach of the Frankfurt School and the work of Chomsky (2013), who accuses the US authorities of forming a discourse on terrorism against the liberation movements.

Critical studies have numerous specific and general theoretical reports, in particular on the isolation and stigmatisation of the Islamic community by the British government (Norris, 2015), on the use of terrorism discourse in international politics as a "weapon of power" (Lorenzana del Villar, 2018), using the concept of combating violent extremism to ensure US foreign policy (Ambrozik, 2018), etc. Alternative theoretical directions are represented by the study of the role of gender in international terrorism (Pearson and Zenn, 2021; White, 2020), or the interpretation of the role of Islamophobia in the perception of the problem of international terrorism by Western societies (Karipek, 2020).

More productive are the specific studies of modern international terrorism as regards its most common movements or tactics. Ibrahim's (2020) typical report on such research provides a thorough overview of the activities of ISIS in Libya, including an analysis of the social and political aspects of the development of this movement and its political dynamics. Stenersen (2017) examines the current state of the al-Qaeda movement, concluding that it is moving towards a state of global franchise, which embodies the Salafi jihadist ideology and relies on the support of local insurgent movements. An assumption is made about the possibility of a new intensification of international terror if it is possible to rebuild its international capacity. Auger (2020) analyses the development, rather expected than real, of far-right terrorism and extremism. In general, we can 
note a wide variety of approaches and methods to the study of international terrorism in the modern literature (Sandler, 2011). Some aspects of the study of international terrorism are attempts to identify the role of radical ideology in its genesis and to find the background for its theoretical analysis.

Holbrook and Hordan (2019) use the model of "cognition, causation and influence" pointing to the non-binary nature of ideological conceptualisation and emphasising the role of social identity in the emergence of ideological foundations of terrorism. The influence of social media on the spread of terrorist movements is a promising area of analysis of the current dynamics of international terror, as Miller (2019) reflected in the study. In the latest research on the problem, the scholar's manifest interest in a range of theoretical areas. The research line on attempts to analyse international terrorist activity through the interaction of two groups of actors - states and terrorist groups through game theory is continued, in particular, in the studies of Hanley (2017), Mumford (2018), Zahedzadeh (2017), etc.

Hawcroft J. - Intelligence Officer and current Head of Anti-Terrorist Programmes of George C. Marshall European Center for Security Studies, provides an overview of the future development of international terrorism in three main areas: motivation, tactics, goals and technologies. The forecast points to the predominant role of social motives in the genesis of terrorist activity of the future, predicting increased violence, attacks on "faceless" corporations as a personification of inequality and the possibility of impulsive, public-driven response of state institutions (Howcroft, 2018). The reverse trend -the reverse shifts from terrorism to legal political activity - is considered, for example, in the report of Ashour (2020).

A separate aspect of the problem is the policy of countries on international terrorism. Murphy's (2017) study of China's policy should be noted here, which is a turning, somewhat new, point. After all, China is moving from its traditional support for radical left-wing Maoism to ensuring stability within its borders, where it faces ethno-national and religious challenges. It should be noted that research on the problem of international terrorism is widely empirically supported. Bowie (2017) provides an overview of 60 key databases on international terrorism.

Thus, in view of academic interest and numerous studies on the problem of international terrorism, the existing drawback is the lack of a stable consensus on the definition of this phenomenon itself. The vast majority of research is determined by unclear methodology and the vagueness of their theoretical provisions (Bakker, 2012), which is true today. Many empirical studies do not have a systemic generalization that would link understanding of international terrorism as a phenomenon in the more or less stable theoretical scheme and provide theoretical grounds for identifying its current trends. 
Ivo Svoboda, Tymur O. Loskutov, Oleksandra B. Severinova, Olha M. Peresada y Andriy O. Shulha

The objectives of this study are to form a systemic view of international terrorism, which must overcome a certain diversity of understanding of the phenomenon in modern academic literature and identify current trends in its development relying on a stable framework for understanding the nature of this phenomenon, as well as internal and external factors for its dynamics.

\section{Methods (research design)}

The research methodology is reduced to four main ideas. Central to the study is the provision of an effective definition of international terrorism, based on a structural and functional approach to the definition of this social phenomenon. We rely on the organisational concept of terrorism provided by Comas et al. (2014) as a polymorphic structural form that combines the features of formal organization, network and social movement. Accordingly, the main actor in international terrorism, which is connected with the direct development of terrorist activity, can be defined as "organisation", "network" or "movement".

The objective of identifying current trends involves the analysis of the dynamics of international terrorism, which is possible through the periodisation of international terrorism and its consistent transformation in accordance with changes in society. This aspect is often overlooked by researchers in constructing generalized concepts of the phenomenon, despite the availability of special intelligence on the connection of international terrorism tactics with certain modern technologies (cyberterrorism) or features of modern society (use of electronic networks by terrorist groups).

Periodisation in the analysis of the dynamics of international terrorism is associated with the method of concentres. It is obvious that research on the problem of international terrorism is often based on the materials of a separate geographical or cultural-geographical centre of the spread of terrorist activity. For example, these are the Middle East, Northern Ireland (British), European centres of the spread of terrorism, which have their own logic of activation and a specific combination of goals and tactics that guide international terrorist groups.

Such centres have a complex cross-border structure that reflects both the interaction within the terrorist movement and its organisational or indirect interaction through informational, cultural, political influences with countries that are so-called "sponsors of terrorism". That is, they are interested in the spread of international terrorist activity as an instrument of their own foreign policy. Such politico-geographical, or geopolitical, in the same sense of the term, zones in which international terrorist activity is formed are defined as "concentres". By the nature of international terrorism, 
the very acts of terrorist activity can take place outside the concentres, being only inspired by the existing political, ideological, and socio-cultural conditions.

The existence of political conditions and interests as organisational structures of international terrorist movements and states - "sponsors of terrorism" requires consideration of their relationship. That is, international terrorist activity must be considered in the context of regional and international policy. The basic assumption of this study is the impact on world (regional) public opinion as the main goal of international terrorist activity in its modern forms, which is achieved by means specific to modern society, and has a political effect set by terrorists.

In general, the hypothesis of current trends in the development of international terrorism takes the form of successive changes within the political and geographical concentres considered in the context of international (regional) policy and general trends in the development of concentre's societies. This structure of the study allows avoiding "monism", which is inherent in a number of studies in determining the decisive cause of terrorist activity, such as religious one, in the definition of "international Islamic terrorism". International terrorism is seen as something that involves: the cross-border scale of the spread of terrorist activity, and the impact on the international (regional) political process.

The data of the Global Terrorism Database (GTD) (n.d.) were used in order to test the hypothesis regarding the periodisation of the dynamics of international terrorism. The database includes information on more than 200,000 terrorist acts (events) since 1970 worldwide. The database is structured according to 135 variables, which allow classifying terrorist acts by time, place of events, actor, scale, content, and a number of other characteristics. The data on the events of the 2000's are the most complete. This fact is a limitation on the study.

\section{Results}

In order to determine the dynamics of global terrorism, the smoothing of a number of data by a polynomial trend line according to the 6th degree equation was used, which most fully reflects the existing trend (Figure 1). 
Ivo Svoboda, Tymur O. Loskutov, Oleksandra B. Severinova, Olha M. Peresada y Andriy O. Shulha

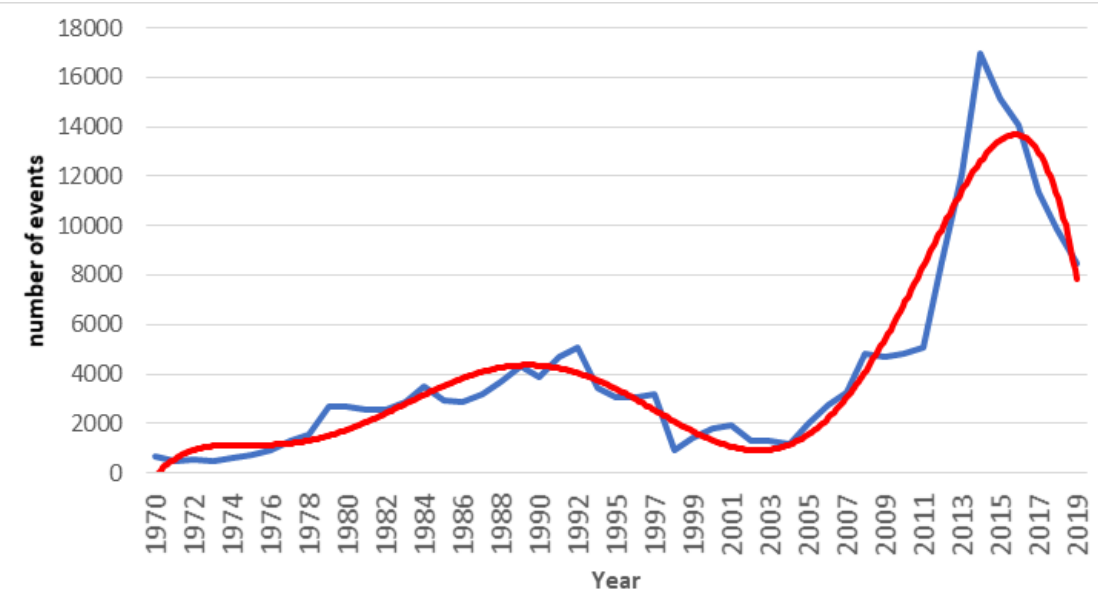

Figure 1. Dynamics of the total number of cases of terrorism in the world, 1970 - 2019 (Global Terrorism Database, n.d).

The trend line reveals two waves of dynamics, which are represented by cycles of rise, peak and decline of terrorist activity worldwide. Detection of peaks allows dividing a series into certain periods. This is done at the breaking points of the trend in its upper and lower peaks. Accordingly, these are the periods: rise $(1970-1990)$, decline (1991 - 2002), rise (2003 - 2016), decline (since 2017). The last cycle is not complete, its downward wave has emerged in the last three years of the study period.

The waves are characterized by increasing intensity (Table 1). This is, respectively, the average of 2,140 cases per year for the period of rise of 1970-1990, 2,722 cases per year for the period of decline in 1991-2002, 6,899 cases per year for the period of rise in 2003-2016, and 9,898 events per year in the period of 2017-2019.

Table 1. Number of cases related to terrorist activity by regions of the world

\begin{tabular}{|c|c|c|c|c|c|c|}
\hline Years & $\begin{array}{c}\text { Australia } \\
\text { and Oceania }\end{array}$ & $\begin{array}{c}\text { Central } \\
\text { America }\end{array}$ & $\begin{array}{c}\text { Central } \\
\text { Asia }\end{array}$ & East Asia & $\begin{array}{c}\text { Eastern } \\
\text { Europe }\end{array}$ & $\begin{array}{c}\text { Middle } \\
\text { East }\end{array}$ \\
\hline $1970-1990$ & 112 & 8,724 & 0 & 287 & 127 & 4,467 \\
\hline $1991-2002$ & 107 & 1,556 & 380 & 359 & 1,602 & 5,886 \\
\hline
\end{tabular}




\begin{tabular}{|c|c|c|c|c|c|c|}
\hline 2003-2016 & 47 & 60 & 176 & 149 & 3,309 & 36,995 \\
\hline $2017-2019$ & 39 & 34 & 18 & 30 & 228 & 9,066 \\
\hline Years & $\begin{array}{c}\text { North } \\
\text { America }\end{array}$ & $\begin{array}{c}\text { South } \\
\text { America }\end{array}$ & $\begin{array}{c}\text { South } \\
\text { Asia }\end{array}$ & $\begin{array}{c}\text { Southeast } \\
\text { Asia }\end{array}$ & $\begin{array}{c}\text { South } \\
\text { Africa }\end{array}$ & $\begin{array}{c}\text { Western } \\
\text { Europe }\end{array}$ \\
\hline $1970-1990$ & 2,190 & 11,783 & 3,522 & 1,628 & 2,268 & 9,848 \\
\hline $1991-2002$ & 758 & 5,228 & 5,313 & 1,847 & 2,712 & 4,194 \\
\hline $2003-2016$ & 435 & 1,807 & 32,712 & 7,992 & 10,612 & 2,298 \\
\hline $2017-2019$ & 315 & 754 & 9,754 & 2,612 & 6,150 & 693 \\
\hline
\end{tabular}

Source: Global Terrorism Database (n.d.)

The first period: $1970-1990$ (rise). In absolute terms, Central and South America dominated by the number of terrorist acts in this period. This structure corresponds to the active concentres of international terrorism. At the time, they corresponded to an active "left wave" in South and Central America, where confrontation between governments and left-wing (or rightwing, as in the case of Nicaragua) guerrilla movements reached the scale of a civil war. Terrorist tactics were part of this war, and widespread external intervention by the Soviet Union and the United States contributed to the internationalization of terrorism. In Western Europe and North America, terrorist activity has also been linked to left-wing movements that have had outside contacts and support from Soviet intelligence. The situation in South Africa was somewhat similar in nature to external intervention, where local anti-government liberation movements also had Soviet support. The development of terrorist activity was connected with the activities of the Soviet special services, and, consequently, with the bloc confrontation. Cross-contacts between terrorist groups, related political movements and Soviet special services have been a factor in the integration of international terrorism.

According to the relative number of terrorist acts per 10 thousand population according to the Global Terrorism Database, the largest terrorist activity for the period was observed in El Salvador (10.5 cases), Lebanon (5.5), Nicaragua (5.5), Rhodesia 3, 1, Peru (2.7), the West Bank and the Gaza Strip (2.5).

Figure 2 presents data on the dynamics and distribution of terrorist acts in El Salvador. The data reflect the dynamics of terrorist acts characteristic of active civil conflict, with periods of escalation and attenuation of the conflict. Attenuation is possible after retreat of the parties, or the party to the conflict from the tactics of terror. In the case of El Salvador, this happened after finding a political solution to the conflict. 
Ivo Svoboda, Tymur O. Loskutov, Oleksandra B. Severinova, Olha M. Peresada y Andriy O. Shulha

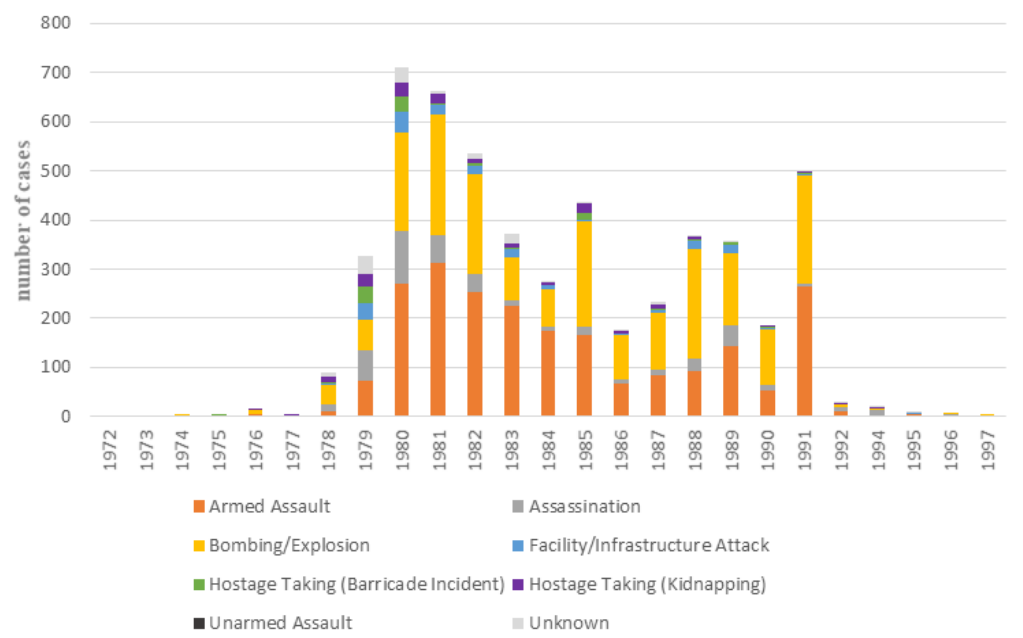

Figure 2. Dynamics and structure of terrorist acts in El Salvador, 1972 1997 (Global Terrorism Database, n.d).

The dynamics is characterized by a high proportion of armed attacks. Murders and bombings accounted for $47.0 \%$ of cases. The structure and dynamics of the El Salvador conflict were typical of the ended conflicts of the period. The events in Bolivia, Peru, Chile, Guatemala, and Nicaragua were similar.

The period is associated with the expanded Middle East concentre of international terrorist activity. Theturning point was the events of the Islamic Revolution in Iran in 1979. The events in Iran inspired the radicalisation of extreme Shiite political movements, giving them a powerful ideological impetus to build an Islamic republic. The leaders of the revolution came out with radical anti-Israel rhetoric without entering into direct military confrontation with this country. Subsequent events have destroyed political stability in Lebanon, creating a political base for regional military-political movements in the country that relied on terrorism, especially the Hezbollah movement.

At the same time, this stage was characterized by a more explicit and active participation of countries in supporting terrorist movements and terrorist tactics. These countries were the Islamic Republic of Iran itself and the countries of the "Iranian axis" - Syria and Libya, the latter was indirectly supported by the USSR. The structure and nature of the struggle at that time gave grounds for US diplomacy to talk about the phenomenon 
of "state terrorism" (Finn and Momani, 2017). Its apotheosis was the 1988 terrorist attack on Lockerbie, which was blamed on Libyan intelligence. The Soviet invasion in Afghanistan in 1979 complicated the confrontation by weakening its position. The terrorist activity of the 1980's took place against the background of the progressive ideological weakening of socialist movements in the Arab world and the growing rise of their radical Islamic alternative, such as the ideology of the revolution in Iran.

The second period: $1991-2002$ (decline). During this period, there has been a significant decline or cessation of terrorist activity in the concentres of Central and South America - with the exception of Colombia. In Western Europe, in South Africa this is clearly linked to the achievement of a political settlement and the cessation of the situation of bloc confrontation.

In this period, there is no clear focus on any of the regions. There is some aggravation in some regions, where the parties to the civil conflict are turning to tactics of terror. The share of terrorist activity cases in the Middle East, South and Central Asia is increasing. This was due to the active phase of the conflicts in Algeria, Pakistan, and the continuing confrontation in Lebanon.

The structure of terrorist activity cases in Lebanon (Figure 3) shows a slightly different situation from the guerrilla war of the previous period. Bombings and killings play a predominant role, which account for $79.4 \%$ of terrorist acts. In Pakistan it is 56.5\%, in Algeria - 50.0\%, in Colombia $53.8 \%$, in the Palestinian Authority and the Gaza Strip - 48.9\%.

In the 1990's, there was a steady downward trend in the number of international terrorist acts (Tilly, 2004:7). Despite the emergence of global satellite news channels in the early 1990's, which objectively multiplied the effects of terrorist acts, international terrorism was experiencing a decline caused by some deadlocks of the struggle in its leading concentres. As a result of the Iran-Iraq war, the First Gulf War, and the collapse of the military bloc system, a combination of circumstances led to the temporary deradicalization of the leading motive for terrorist activity in the Middle East, the Arab-Israeli confrontation in Palestine. The "sponsors of terrorism" states were losing their political motives to actively support anti-Israel movements; in the social realities of the 1990's, symbolic acts of terror on a global scale could not find a resonance, and Israel itself was involved in a compromise-oriented dialogue. In European and South Asian concentres, terrorist activity has been declining since the early 1980's due to political changes that discredited radical communist ideology. 
Ivo Svoboda, Tymur O. Loskutov, Oleksandra B. Severinova, Olha M. Peresada y Andriy O. Shulha

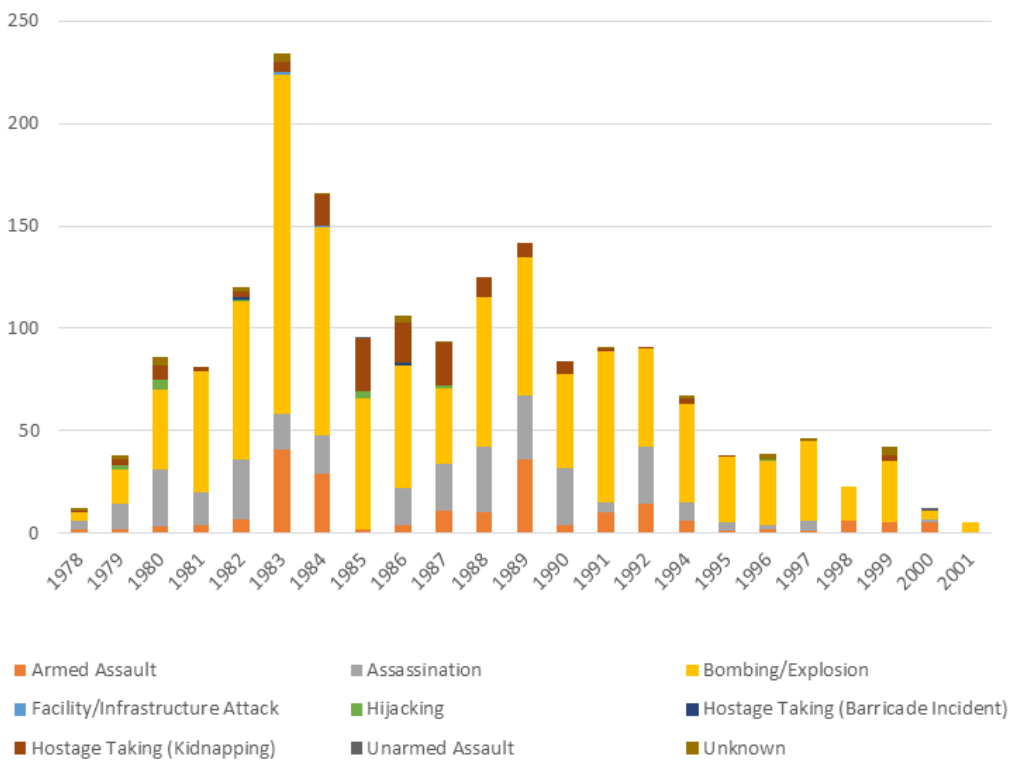

Figure 3. Dynamics and structure of terrorist acts in Lebanon, 1978 2001 (Global Terrorism Database, n. d.)

Third period: $2003-2016$ (rise), the beginning of the upward wave of 2017 - 2019. During this period, the role of political events related to the War on Terror, the leading events of which were the US invasion in Iraq and Afghanistan, and with the Arab Spring in the early 2010's, is unconditional. At the beginning of the period, three countries in the Middle East and South Asia - Iraq, Afghanistan, and Pakistan - accounted for more than half of the total number of terrorist attacks. The structure of cases in Iraq is similar to that in Lebanon, with an even higher proportion of bombings of 73.4\%. In 2013-2019, the number of terrorist attacks in Syria, Egypt and Libya became noticeable. Since 2015, suicide bomber attacks as the basis of ISIS terrorist tactics have become a significant phenomenon. A number of countries, where there was a decline in terrorist activity in the previous period, experienced a new cycle of confrontation. In particular, Colombia, Turkey, Lebanon, Sri Lanka, and the Philippines experienced the second wave of terrorist activity.

Figures 4 and 5 show the structure of terrorist attacks in Lebanon during the active phase of the conflict in 1979-1989, and in Afghanistan in 20032019. 


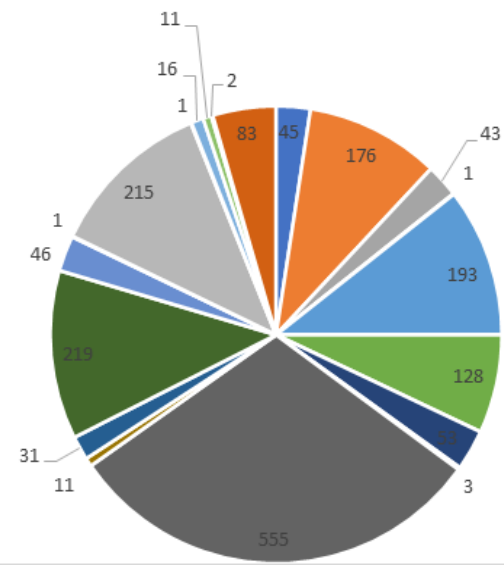

- Airports \& Aircraft

" Business

= Educational Institution

= Food or Water Supply

= Government (Diplomatic)

- Government (General)

- Journalists \& Media

- Military

- NGO

- Other

- Police

- Private Citizens \& Property

- Religious Figures/Institutions

= Telecommunication

= Terrorists/Non-State Militia

= Tourists

= Transportation

= Unknown

- Utilities

- Violent Political Party

Figure 4. Targets of the terrorist attacks in Lebanon during the active phase of the 1979-1989 conflict (Global Terrorism Database, n.d.)

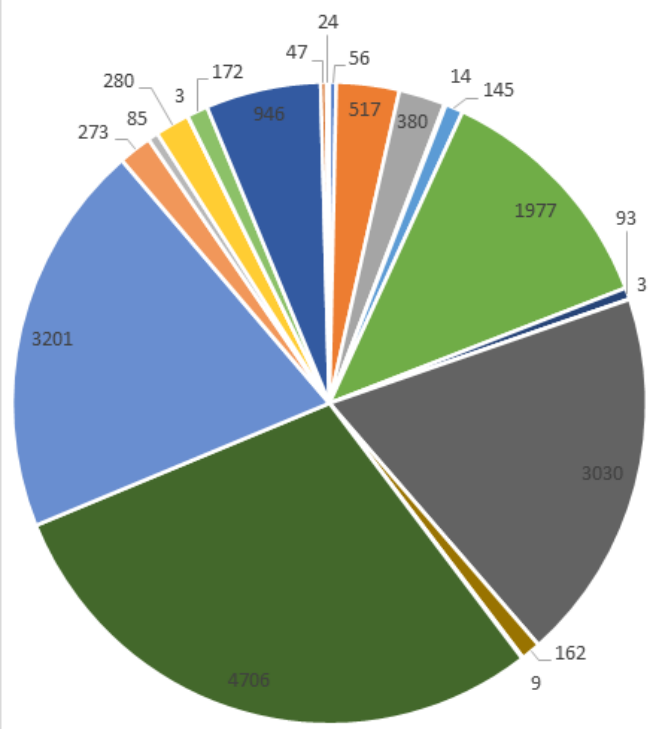

- Airports \& Aircraft

\# Business

- Educational Institution

" Food or Water Supply

- Government (Diplomatic)

= Government (General)

- Journalists \& Media

- Maritime

- Military

- NGO

- Other

- Police

- Private Citizens \& Property

= Religious Figures/Institutions

= Telecommunication

= Terrorists/Non-State Militia

" Tourists

= Transportation

- Unknown

- Utilities

- Violent Political Party

Figure 5. Targets of terrorist attacks in Afghanistan during the active phase of the 2003-2019 conflict (Global Terrorism Database, n.d.) 
Ivo Svoboda, Tymur O. Loskutov, Oleksandra B. Severinova, Olha M. Peresada y Andriy O. Shulha

594

Current Trends in the Development of International Terrorism: A Current Understanding of the Problem

As we can see, they are typically similar, with the difference that the targets of terrorist attacks in Lebanon were more often private individuals, non-governmental military units and diplomatic missions. This reflects the peculiarities of the political confrontation in the country.

The identification of concentres of terrorist activity indicates the following sequence of stages in the development of global terrorism. International terrorism is a changing problem in modern international relations. According to Google Books Ngram Viewer, interest in it arose after World War II and began to grow rapidly from the early 1970's, when the resonant acts were made, and 2004 with a significant decline in the mid-1990's and in present.

The first stage covers the end of the 1960's - 1970's. This stage in the development of international terrorism is associated with the Middle East (Israel and Palestine) and European centres of terrorist activity. The transition to international terrorist activity in the Middle East was obviously due to a set of circumstances - the loss of confidence of the societies of Arab countries in the possibility of achieving a military victory over Israel, the radicalisation of the Palestinian diaspora, political changes in Western societies. The Doomsday War of 1973 finally revealed Israel's military superiority over its immediate opponents - Egypt and Syria, which had the opposite effect. The beginning of the Camp David process and the search for peaceful coexistence by Egypt, and the transition of Palestinian groups, including the Palestine Liberation Organization, to asymmetric action tactics. Resonant terrorist acts of the 1970's: the terrorist attacks in Munich (1972), at the airport in Lod (1972) and in Harturm (1973) were striking examples of attacks on symbolic objects to demoralise society of Israel and an attempt to achieve changes in public opinion in the West. On the one hand, such acts created the image of terrorists for the Palestinian movement, on the other hand, they urged the theme of the struggle in the Middle East in public opinion, providing an information pretext and a platform for pro-Palestinian intellectuals.

The shifts in Western societies have made this tactic quite rational for many reasons. The 1970's were a turning point in the end of the "Glorious Thirty Years" - the military and pre-war generations departed from active participation in public life, the active post-war generation of intellectuals at that time was formed in the conditions of the anti-war campaigns of the 1960's and suffered the consequences of the economic shocks of the early 1970's, which ended the period of continuous post-war rise. The spread of colour television for the first time allowed broadcasting "real-time terrorist attacks" to an international audience. A set of complex influences on public opinion led to the emergence of the intellectual movement represented by $\mathrm{N}$. Chomsky. The anti-war and radical sentiments created during the Vietnam War were transferred to the realities of the Middle East and to the political 
support for Israel by the governments of the United States and other Western countries. Palestinian terrorism has received direct or indirect support from other political forces interested in destabilising Israel and Western societies, most notably the Soviet Union, its satellites, and its allies.

At the same time, the actual European concentre of international terrorism, represented by radical left-wing terrorist organisations, was being formed. Red Brigades, the Red Army Faction, and others deployed at the turn of the 1960's and 1970's amid destroyed hopes of radical change during the events of the May 1968 Revolution in France, the political isolation of the Communist Party in Italy, and the limited political capabilities of Europe's radical left-wing movements in a military bloc confrontation.

The concentre of terrorist activity in Southeast Asia has been linked to the spread of Maoist ideology and the support of the Chinese Communist Party, which has inspired and influenced Chinese ethnic minorities in the region.

Thus, the stage includes the Middle East concentre being associated with shifts in the societies of the region. It is based on the emergence of radical fundamentalist ideologies, embodied by the al-Qaeda movement, and the largest symbolic act - the attack on the Twin Towers in New York on September 11, 2001. We consider the political impasse in the modernisation of societies in the region achieved at the beginning of the $21^{\text {st }}$ century to be the root cause of the transition to asymmetric actions and symbolic attacks at this stage. Authoritarian regimes with exhausted opportunities to develop their own ideology (that is authoritarian regimes in crisis of legitimacy), demographic collapse, culture shock from modernisation combined with insufficient economic growth and a high degree of social inequality - this set of circumstances is extremely favourable for the development of radical ideologies and radical movements, the suppression of which leads them to the practice of asymmetric actions.

While the acquisition of a regional scale by terrorism in the Middle East can be explained by the region's Arab and Islamic unity, its international and anti-Western, anti-American orientation will need to be further explained. The United States also act as the embodiment of modernization shifts opposed by the radical ideology of Islamic fundamentalism; and as a political partner of authoritarian regimes against which radical movements are directed; and as the object of traditional criticism by these regimes, which often base their ideology on anti-Americanism. In this sense, the terrorist struggle of the 2000's is seen as a direct response to the process and ideology of globalisation.

Thus, the current trends of modern international terrorism should be seen in the development of the logic of the development of terrorist activity of its leading centres in modern social and political conditions. We consider 
Ivo Svoboda, Tymur O. Loskutov, Oleksandra B. Severinova, Olha M. Peresada y Andriy O. Shulha

the events of the Arab Spring of 2010 to be the driving force behind this process. The Arab Spring of 2010 has to some extent covered most of the countries of the large (including North Africa) Middle East region. But not in all cases has it led to the establishment of a regular competitive political process, which creates risks of a shift to asymmetric action and political violence. As it turned out, this mainly applies to countries where there has been a collapse of societies and state power - Libya, Syria, northern Iraq.

The emergence of the ISIS movement and its rapid military-political successes, the promotion of an effective radical fundamentalist ideology that combines the features of Islamic Reformation and fascism is "a truly modern totalitarian project", as defined by Lohlker (2017), put the region the threat of a global collapse, the political consequences of which and their unacceptability for the international community are obvious. Joining forces for the confrontation of ISIS, which by the middle of the decade acquired the features of a state and conducted "almost" conventional military confrontation with the region (embodying the so-called "fifth wave" of international terrorism - the emergence of "semi-states" formed by terrorist movements (Honig and Yahel, 2019), inevitably put this movement before the alternative of using asymmetric actions, which was the case on a large scale.

The international terrorist movement personified by the ISIS has acquired a number of innovative features. They include the widespread use of the media and tactics of network terror. ISIS distinguished by the systemic creation of directed acts of symbolic terror actively using electronic media and social networks for the broadcast. Even acts of military cruelty, such as mass executions and the extremely widespread use of suicide bombers, were given the form of acts of symbolic terror and broadcasted to a wide audience. The tactics of network terror are the involvement of random supporters in terrorist acts, who are not organisationally connected with the movement, but organise terrorist acts in accordance with the campaign materials created by the movement and terrorist campaigns launched by the movement. Terror initiated in this way acquires the features of spontaneity, unpredictability, mass, promotes the emotional involvement of entire ethnic or social categories of people and the accelerated formation of appropriate stereotypes of public opinion. The mass migrations of refugees that accompanied the events of the mid-2010's exacerbated this trend.

An effective fundamentalist ideology, a network structure that brings this terrorist wave closer to defining the movement than to the organization, along with the practice of network terror contributes to the further spread of the Middle East concentre and its reach of the territorial borders of Central Africa (including existing Muslim communities, including where the Boko Haram movement operates), and to Europe, where migration results in the formation of Islamic communities in which activists of radical movements operate. 


\section{Discussion}

The given understanding of the dynamics and current state of international terrorism, as noted, is based on the understanding of its content as a triad: asymmetric actions, attacks on symbolic objects, the focus on public opinion. This is different from Crenshaw's (1981) traditional model, which structures individual motives for terrorist behaviour, group decision-making and strategy development, and the broad socio-political context in which terrorist activity develops, and which is too broad and schematic to understand the root of the phenomenon.

In the modern literature, the discussion around terrorism has focused on the content of the radicalisation process with analytical models of political terrorism, which are developed on modern materials, aimed at building models of involvement in terrorist activity being close to sociopsychological models. Thus, Moghaddam's (2005) "steps" model considers involvement in terrorism as an evolution in the views of an individual who joins a terrorist organisation. Today, a group of concepts has been developed on its basis, including the concept of two pyramids - views and actions (McCauley and Moskalenko, 2008). The attitudes-behaviours corrective (ABC) model also focuses on mechanisms to justify violence in the organisation of terror campaigns (Khalil et al., 2019).

The focus on such models ultimately theoretically equates terrorism and international terrorism with acts of political violence, conceptually reducing them to individual nature. That can reduce the problem even to definitions of "mental disorder", which can sometimes be found even in recent works (Kruglanski et al., 2017; Kunst et al., 2018). Even political models of terrorism are based on the understanding of terrorism as the beginning of a closed autonomous group (Kudinov et al., 2020; Wilkinson, 2011).

The proposed approach is rationalistic in the sense that international terrorism is seen as a rational political strategy that has its own logic of application and is embedded in a sequence of other, including conventional, means of political confrontation. It is obvious that such an approach on the basis of modern materials can solve the dilemma of definitions and reach a lasting consensus on the framework structure of the academic definition of terrorism and international terrorism. The distinction between international terrorism and other forms of radical political struggle, which is not reduced to political violence (Sysoev, 2017), can be identified and clearly traced, and identifications with revolutionary movements are avoided (Anderson, 2015).

The given understanding of modern terrorism in the context of its development allows removing the characteristic of the critical approach "deconstructive" interpretations of international terrorism in the spirit 
Ivo Svoboda, Tymur O. Loskutov, Oleksandra B. Severinova, Olha M. Peresada y Andriy O. Shulha

598

Current Trends in the Development of International Terrorism: A Current Understanding of the Problem

of the Chomsky's (2013) school. A clear understanding of terrorism as a rational strategy is determined by the frequency of stages of development and its own political logic, which eliminates the uncertainty of definitions, removes the problem of "constructed" discourses and "stigmatisation" (Lorenzana del Villar, 2018; Norris, 2015).

The results of the study raise a number of theoretical issues that require further research. In particular, on the mechanisms of influence of terrorist acts ("symbolic attacks") on modern society. The expected result of terrorist attacks in Europe was the growth of right-wing terrorism (Bjørgo and Ravndal, 2019) (which is not justified). However, the motives of the terrorist movements themselves, which in the situation of network terror become less predictable and stable, are poorly studied.

Today, a wide range of definitions of the concept of terrorism and international terrorism is used, which distinguish its individual essential features. Consistently, these include the interpretation of terrorism as: politically motivated violence by organised groups against noncombatants, which usually has the purpose of influencing the audience, means of intimidation the use of fear for political, religious or ideological purposes (Lykhova et al., 2021; Schmid, 2004) directed activities against civilian targets by a non-state actor (Ganor, 2018), violent activities aimed at psychological influence (Wang and Zhuang, 2017), a certain culture of terror (Aran, 2019).

Analysis of the definitions of terrorism in the context of its political dynamics points to the key objectives of international terrorist activity and its differences from other types of conventional and unconventional actions in armed conflicts. First, international terrorism develops as a means of asymmetric action - it is an asymmetric response in a confrontation of a terrorist movement with a party to the conflict (almost always it is the political regime of a country or group of countries) when this confrontation cannot be reduced to a certain, possibly negative balance of power. That is, when the opposing party has a sufficient advantage in conventional forces and means to obtain a complete victory. Therefore, the transition to terrorist activity is dictated by the forced need for asymmetric unconventional confrontation. Second, such activity does not have the power structures of the opposite side as its direct addressee. Although they may be the target of individual terrorist acts, directing terrorist activity at them in certain conditions of confrontation does not make sense, because due to the fundamental difference in force potentials, it cannot lead to victory in the military confrontation.

The targets of terrorist attacks are symbolic objects, and the addressee is national, regional or world public opinion. Thus, thirdly, the victory in the asymmetric confrontation waged by terrorist means is achieved through the influence on public opinion and the initiation of negative processes for 
the policy of the ruling regime. The desired result of terrorist attacks is the discrediting of the ruling political forces and their leaders, the initiation of civil disobedience campaigns, the destabilisation of the political situation and the formation of a political crisis, the deepest demoralisation of society. The third consequence follows from this - international terrorism is a struggle for public opinion, terrorist acts are symbolic acts. The struggle, which in the conditions of a more favourable balance of power turns into a sabotage against government officials and law enforcement agencies in order to gain direct political control over the territory is no longer terrorism in the modern sense of the word. Here is the divide between terrorism and other forms of unconventional confrontation - guerrilla warfare, insurrection, political revolution. It is clear from this understanding where terrorism and other types of unconventional confrontation can intersect and intertwine (for example, according to the spectrum of non-state combatants provided in the classification of Zohar (2016).

The ability to provide a symmetrical force response and to wage a symmetrical struggle, such as a military one, encourages the retreat from terrorist means, as they are less advantageous in terms of resources and benefits, and the struggle for territory - gaining political power - is the ultimate goal of political struggle. Acts of symmetrical confrontation which resemble terrorism are diversions in nature.

The difference between international and national (domestic) terrorism is the difference in the scale of public opinion on which the influence achieved by means of terrorist activity is directed. In the case of domestic terrorism, it is national public opinion, and the confrontation takes place in a national symbolic and informational context. In the case of international terrorism, the confrontation takes place in a more complex context, which includes global public opinion and national one, for example, within the region. The terrorist struggle presupposes the availability of effective mass media for the transmission of a symbolic act to public opinion. In case of international terrorism, it is the international media, and with the advent of electronic sources - cross-border media.

\section{Conclusions}

The study of current trends in the development of international terrorism istopical duetotheacutepolitical urgency and variabilityof this phenomenon. The study of international terrorism, as well as terrorism in general, despite the long history and rootedness of the phenomenon in modern politics, has a problem of lack of academic consensus on the fundamental problems of defining this phenomenon, which indicates problems with understanding its nature, thus complicating the understanding of its current state and 
Ivo Svoboda, Tymur O. Loskutov, Oleksandra B. Severinova, Olha M. Peresada y Andriy O. Shulha

600

Current Trends in the Development of International Terrorism: A Current Understanding of the Problem

dynamics of development. The dilemma of definitions inherent in the study of international terrorism allows us to even form concepts for the deconstructive refutation of this phenomenon as existing only as a phantom concept in the imposed repressive discursive practices.

The study proposed a clear model for understanding international terrorism as a rational strategy for unconventional political struggle. This model is based on three successive principles: the transition to asymmetric actions, attacks on symbolic targets, influencing public opinion as the main goal. Such a triad of features, linked to a model of the political process, defines the existence of international terrorism as a phenomenon and provides a key to understanding its dynamics.

The proposed periodisation of the development of international terrorism is based on the identification of concentres as political and geographical zones in which contradictions are formed and the political struggle that they inspire, which is part of the logic of terrorist strategy. We distinguish five stages in the development of international terrorism (late 1960's - 1970's, 1980's, “pause” of the 1990's; 2000's and 2010's), which have a single internal logic, but differ in external circumstances due to the participation of external actors and changes in the development of societies.

Prospects for future research include an analysis of the mechanisms of the impact of symbolic attacks on targeted public opinion, the role of modern online media and the level of perception of international terrorism by modern societies.

\section{Bibliographic References}

AMBROZIK, Caitlin. 2018. "To change or not to change? The effect of terminology on public support of countering violent extremism efforts" In: Democracy and Security. Vol. 14, No.1, 45-67.

ANDERSON, Eric C. 2015. "Confusing a "Revolution" with "Terrorism". Available online. In: https://smallwarsjournal.com/jrnl/ art/confusing-a-\%e2\%80\% 9crevolution\%e2\% 80\% $9 \mathrm{~d}$-with\%e2\%80\%9cterrorism\%e2\%80\%9d. Date of consultation: 20/01/2021.

ARAN, Gideon. 2019. "Striking home: ideal-type of terrorism" In: Terrorism and Political Violence. Vol. 31, No. 5, pp. 987-1005.

ASHOUR, Omar. 2020. "From Bullets to Ballots. Transformations from Armed to Unarmed Political Activism. Arab Center for Research \& Policy Studies". Available online. In: www.jstor.org/stable/resrep25870 Date of consultation: 20/05/2021. 
AUGER, Vincent A. 2020. "Right-wing terror: A fifth global wave?" In: Perspectives on Terrorism. Vol. 14, No. 3, pp. 87-97.

BAKKER, Edwin. 2012. "Forecasting terrorism: the need for a more systematic approach" In: Journal of Strategic Security. Vol. 5, No. 4, pp. 69-84.

BJØRGO, Tore; RAVNDAL, Jacob Aasland 2019. "Extreme-Right Violence and Terrorism: Concepts, Patterns, and Responses". Available online. In: https://icct.nl/publication/extreme-right-violence-and-terrorismconcepts-patterns-and-responses. Date of consultation: 20/05/2020.

BOWIE, Neil G. 2017. "Terrorism events data: An inventory of databases and data sets, 1968-2017" In: Perspectives on Terrorism. Vol. 11, No. 4, pp. 50-72.

CHOMSKY, Noam. 2013. The Definition of Terrorism. In: AKSAN, Cihan; BAILES, John (Eds.), Weapon of the Strong, pp. 32-46. Pluto Press, London, UK.

COMAS, Jordi; SHRIVASTAVA, Paul; MARTIN, Eric C. 2014. "Terrorism as formal organization, network, and social movement”. In: Journal of Management Inquiry. Vol. 24, No. 1, pp. 47-60.

CRENSHAW, Martha. 1981. "The causes of terrorism” In: Comparative Politics. Vol. 13, No. 4, pp. 379-399.

FINN, Melissa; MOMANI, Bessma. 2017. "Building foundations for the comparative study of state and non-state terrorism" In: Critical Studies on Terrorism. Vol. 10, No.3, pp. 379-403.

GANOR, Boaz. 2018. "MIA: An International Definition for Terrorism" Available online. In: https://www.eng.arenajournal.org.il/single-post/ Ganor-Terrorism-ENG Date of consultation: 20/05/2021.

GARRISON, Arthur H. 2004. "Defining terrorism: philosophy of the bomb, propaganda by deed and change through fear and violence" In: Criminal Justice Studies. Vol. 17, No. 3, pp. 259-279.

GLOBAL TERRORISM DATABASE. n.d. Available online. In: https://www. start.umd.edu/gtd/ Date of consultation: 20/05/2020.

HANLEY, John T. 2017. "Planning for the kamikazes: toward a theory and practice of repeated operational games" In: Naval War College Review. Vol. 70, No. 2, pp. 29-48.

HOLBROOK, Donald; HORGAN, John. 2019. "Terrorism and ideology: Cracking the nut” In: Perspectives on Terrorism. Vol. 13, No. 6, pp. 2-15. 
Ivo Svoboda, Tymur O. Loskutov, Oleksandra B. Severinova, Olha M. Peresada y Andriy O. Shulha

602 Current Trends in the Development of International Terrorism: A Current Understanding of the
Problem

HONIG, Or; YAHEL, Ido. 2019. "A fifth wave of terrorism? The emergence of terrorist semi-states" In: Terrorism and Political Violence. Vol. 31, No. 6, pp. $1210-1228$.

HOWCROFT, James. 2018. "The future of terrorism: The practitioners' view" In: Connections. Vol.17, No. 2, pp. 77-81.

IBRAHIM, Azeem. 2020. "Rise and Fall? The Rise and Fall of ISIS in Libya". Available online. In: http://www.jstor.org/stable/resrep26531. Date of consultation: 20/05/2020.

JENKINS, Brian M. 1978. "International terrorism: trends and potentialities" In: Journal of International Affairs. Vol. 32, No. 1, pp. 115-123.

KANE, J. Robert. 2018. Terrorism Defined and Why It Matters. Available online. In: https://smallwarsjournal.com/jrnl/art/terrorism-definedand-why-it-matters. Date of consultation: 20/05/2020.

KARIPEK, Asena. 2020. "Portrayals of Jihad: A cause of Islamophobia" In: Islamophobia Studies Journal. Vol. 5, No. 2, pp. 210-255.

KHALIL, James; HORGAN, John; ZEUTHEN, Martine. 2019. "The attitudesbehaviors corrective (abc) model of violent extremism" In: Terrorism and Political Violence. Available online. In: https://doi.org/10.1080/09 546553.2019.1699793. Date of consultation: 20/05/2020.

KRUGLANSKI, Arie W; JASKO, Katarzyna; CHERNIKOVA, Marina; DUGAS, Michelle; WEBBER, David. 2017. "To the fringe and back: Violent extremism and the psychology of deviance" In: American Psychologist. Vol. 72, No. 3, pp. 217-230.

KUDINOV, Serhiy S.; BROVKO, Nataliia I.; STOLBOVYI, Volodymyr M. 2020. "International Experience of Legal Service Relations in the National Security Sphere: Issues of Implementation in Ukraine" In: Cuestiones Políticas. Vol. 37, No. 65, pp. 156-168.

KUNST, Jonas R; MYHREN, Lisa S; ONYEADOR, Ivuoma. N. 2018. "Simply insane? Attributing terrorism to mental illness (versus ideology) affects mental representations of race" In: Criminal Justice and Behavior. Vol. 45, No. 12, pp. 1888-1902.

LOHLKER, Rüdiger. 2017. "Excluding the other: Wahhabism, Salafism, Jihadism, and political Islam" In: Totalitarianism and Democracy. Vol. 14, No. 2, pp. 265-290.

LORENZANA DEL VILLAR, Erika Mae. 2018. Our Holy Grail: States, Power, and Networks in the Stymied Global Quest to Define Terrorism. Doctoral dissertation. University of Connecticut. Storrs, USA. 
LYKHOVA, Sophia Ya.; LEONOV, Borys D.; LYSKO, Tetiana D.; SHAPTALA, Natalya K.; MAKSYMOV, Sergiy I. 2021. "Criminal-legal ensuring of freedom of religion in modern conditions: A comparative analysis" In: Cuestiones Políticas, Vol. 39, No, 68, pp. 620-649.

MARGARITI, Stella. 2017. "A definition of terrorism in the making: balancing state interests with cosmopolitan ideals.” In: Defining International Terrorism. International Criminal Justice Series. Vol. 15, pp. 145-175.

MCCAULEY, Clark; MOSKALENKO, Sophia. 2008. "Mechanisms of political radicalization: pathways toward terrorism" In: Terrorism and Political Violence. Vol. 20, No.3, pp. 415-433.

MILLER, Gregory D. 2019. "Blurred lines: the new 'domestic' terrorism” In: Perspectives on Terrorism. Vol. 13, No. 3, pp. 63-75.

MOGHADDAM, Fathali M. 2005. "The staircase to terrorism: a psychological exploration” In: American Psychologist. Vol. 6o, No. 2, pp. 161-169.

MONAGHAN, Rachel; ANTONIUS, Daniel; SINCLAIR, Samuel Justin. 2011. "Defining 'terrorism': moving towards a more integrated and interdisciplinary understanding of political violence" In: Behavioral Sciences of Terrorism and Political Aggression. Vol. 3, No. 2, pp. 77-79.

MUMFORD, Andrew. 2018. "Theory-testing Uyghur terrorism in China” In: Perspectives on Terrorism. Vol. 12, No. 5, pp. 18-26.

MURPHY, Dawn. 2017. "China's Approach to International Terrorism" Available online. In: http://www.jstor.org/stable/resrep20167. Date of consultation: 20/05/2021.

NORRIS, Maria. 2015. Contesting Identity and Preventing Belonging? An Analysis of British Counter Terrorism Policy Since the Terrorism Act 2000 and the Selective Use of the Terrorism Label by the British Government. London School of Economics and Political Science (LSE). London, UK.

PEARSON, Elizabeth; ZENN, Jacob. 2021. "A Gender Lens, Terrorism and Boko Haram". Available online. In: http://www.jstor.org/stable/ resrep29499.5. Date of consultation: 20/05/2021.

SANDLER, Todd. 2011. "New frontiers of terrorism research: An introduction" In: Journal of Peace Research. Vol. 48, No. 3, pp. 279-286.

SCHMID, Alex. 2004. "Terrorism - the definitional problem" In: Case Western Reserve Journal of International Law. Vol. 36, No. 2, pp. 375-419. 
Ivo Svoboda, Tymur O. Loskutov, Oleksandra B. Severinova, Olha M. Peresada y Andriy O. Shulha

604 Current Trends in the Development of International Terrorism: A Current Understanding of the
Problem

SCREMIN, Nicolò. 2020. "Why an agreed definition of terrorism matters." In: International Counter-Terrorism Review, Vol.1, No, 2, pp. 1-11.

STENERSEN, Anne. 2017. "Thirty Years after its foundation - where is AlQaida going?” In: Perspectives on Terrorism. Vol. 11, No. 6, pp. 5-16.

SYSOEV, Sergei Borisovich. 2017. "Terrorism as a political violence: the formula" In: Journal of Applied Security Research. Vol. 12, No. 3, pp. 407-414.

TILLY, Charles. 2004. "Terror, terrorism, terrorists” In: Sociological Theory. Vol. 22, No. 1, pp. 5-13.

WANG, Tao; ZHUANG Jun. 2017. "The true meaning of terrorism and response to terrorism" Social Sciences. Vol. 6, No. 6, pp. 160-168.

WHITE, Jessica. 2020. "Community and Gender in Counter-Terrorism Policy: Challenges and Opportunities for Transferability Across the Evolving Threat Landscape" Available online. In: http://www.jstor.org/stable/ resrep29447. Date of consultation: 20/05/2021.

WILKINSON, Paul. 2011. Terrorism Versus Democracy. 3rd edition. Routledge. London, UK.

ZAHEDZADEH, Giti. 2017. "Containing terrorism: A dynamic model" In: Journal of Strategic Security. Vol. 10, No. 2, pp. 48-59.

ZOHAR, Eran. 2016. "A new typology of contemporary armed non-state-actors: Interpreting the diversity" In: Studies in Conflict \& Terrorism. Vol. 39, No. 5, pp. 423-450. 
Vol. 39 N $^{\circ} 69$

Esta revista fue editada en formato digital y publicada en julio de 2021, por el Fondo Editorial Serbiluz, Universidad del Zulia. Maracaibo-Venezuela 